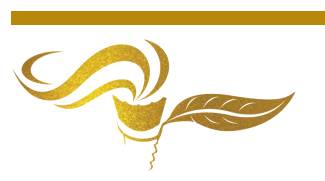

\title{
Understanding the Impact of the COVID-19 Pandemic on Student Nurses - A Transdisciplinary Problem
}

\author{
Aygun Muradli $i^{1}$ and Paul Gibbs ${ }^{2}$ \\ 1 Azerbaijan University, Azerbaijan \\ 2 Emeritus Professor, Middlesex University, London, UK \\ * Correspondence: Email: p.gibbs@mdx.ac.uk
}

Received 27 November, 2020; Revised 6 February, 2021; Accepted 6 February, 2021

Available online 7 February, 2021 at www.atlas-journal.org, doi: 10.22545/2021/00156

\section{Short Letter}

The COVID-19 pandemic has had a devastating impact across Azerbaijan. Official statistics suggest that there have been well over 3000 COVID-19 deaths in Azerbaijan, and this is generally accepted to underestimate the true number. There is growing evidence that health and social care workers appear to have a heightened risk of infection and mortality as do people from Black, Asian and Minority Ethnic (BAME) backgrounds. For example an analysis of COVID-19 deaths at St George's hospital in the UK demonstrated a similar age distribution to deaths normally observed in the hospital which was in contrast with BAME communities who were "disproportionately affected by COVID-19 and non-COVID deaths, and the excess in mortality in the BAME groups remains after adjustment and is not fully explained by available hospital information on comorbidities age, sex or poverty". (Perkin et al, 2020:70 [1]).

It is clear that the challenges which all students are experiencing have been magnified for those studying to enter these medical professions, but each in very different ways. In nursing and midwifery students have been offered the opportunity to opt for extended placements within NHS services to support the national response to COVID-19 (Jackson et al, 2020 [2]). Each of these different options presents both challenges and opportunities for students. These students are likely to have a range of experiences, both positive and negative and may be placed in challenging situations; some predicable, others potentially unforeseen. Nurses have been in the front line of the response to COVID-19 with many being redeployed as in-patient services were reconfigured to ensure the health service retains the capacity to treat the expected large numbers of patients with COVID-19. In parallel, the public health response to the pandemic with its twin principles of 'social distancing' and the 'self-isolation' imposed during a national 'lockdown' present huge challenges. Social care services have had to manage unprecedented social upheaval. Social workers have had to rapidly adjust their practice in order to discharge their statutory responsibilities. For community based mental health nurses the best practice principles of patient centred and recovery focused care have been fundamentally challenged by the need for social distancing, while for midwifes whether working in the 
community or in hospital the need to maintain both patient and personal safety generate extraordinary challenges and require complex decision-making.

For example, year two students, expressed that they had fears about the loss of academic time during the extended placement and the pressure this brought to catch up on hours during the final year of their programme. For some, this carries with it a fear of not being able to achieve their best in academic work now or later Swift et al (2020: 3113 [3])

As Swift et al (2020 [3]) asserts, professional identity is important to nurses. There is an intrinsic reward in being a nurse that for some is linked to the notion of nursing as a vocation or a calling, and many students describe this as a key driver in their choice of career (Eley, et al, 2012 [4]).

This could occur because professional identity is so closely connected to knowledge and experience and linked to their agency which itself is vulnerable as well as their own health. It therefor follows that thus, professional identity is always dependent upon personal identity (Holmesland, 2010:3 [5]). The research paradigm follows in the most part that developed by Lawrence (2020 [6]) which proposes a transdisciplinary conceptual framework represents a complex and dynamic open system in which each set of variables has unique properties in response to the emergence, complexity and uncertainty of student identity. It requires "several types of resources, coordinated multi-level governance, and individual and collective behaviours, that should be combined in transdisciplinary contributions" (2020:196 [6]).

For BAME students the pressure on self and professional identity in the context of a colonial context with racism evident in the societies for which they work, the situation is more confusing and anxiety inducing. Add to this the higher chance of death and the belated recognition of the specific risks to BAME students and the delayed process to ameliorate these risk. It is suggested that BAME students in Nursing and Midwifery are particularly vulnerable. At Middlesex University students from BAME backgrounds make up around two thirds of the nursing student population and research by Moorthy and Sankar (2020 [7]) indicated that more than $70 \%$ of BAME of medical care workers were anxious about their role during the pandemic and concluded that current anxiety level is very high and "adequate provision of mental health support with clear risk stratification for return to work is required urgently" (2020:486 [8]). Supportive of this position Albott et al, (2020 [8]) observed the need to identify mental health concerns and for those medical care students studying for professional qualifications in nursing and midwifery the impact has been particularly significant. The research attempts to understand the experiences of these students.

\section{Situation in Azerbaijan}

As the Covid-19 pandemic began to spread to other countries, a number of precautions were taken in the country. As a precautionary measure, an order was signed in January to establish an Operational Headquarters under the Cabinet of Ministers of the Republic of Azerbaijan.

The first quarantine regime in Azerbaijan was signed on March 23, 2020 under the leadership of Prime Minister A. Hasanov. During this period, it was decide to:

1. 1. Prohibit people over the age of 65 from leaving home.

2. Restrict access to and exit to Baku, Sumgayit and Absheron districts, except for the movement of special purpose vehicles, including ambulances, emergency response, rescue, as well as trucks.

3. Suspend the activity of district and intercity passenger transportation in the country, regardless of the type of property.

4. Ensure that families with young children, the elderly, persons in need of medical care and women are brought to Azerbaijan by special charter flights with compulsory quarantine for 14-21 days within the established schedule, giving preference to women.

5. Baku Transport Agency to apply special express bus lines between 06:00 and 22:00 on the basis of the established route between metro stations. Passengers are advised to minimize the use of the subway, to use transport. 
6. Prohibit the concentration of individuals in groups of more than 10 people in public places, including streets, boulevards, parks and other places.

7. Recommend that citizens keep a distance of 2 meters in interpersonal contacts.

8. Apply a new mode of work to public catering establishments: to set the time of on-site service for customers from 12.00 to 15.00 , to allow home pick-up, delivery and online sales without restrictions;

9. Suspend the activity of shopping centers and malls in the country, except for nearby supermarkets, grocery stores and pharmacies;

10. Ensure the operation of food stores, pharmacies and other vital facilities.

11. Entrust control over the implementation of the requirements of the special quarantine regime to the Ministry of Internal Affairs of the Republic of Azerbaijan. (https://nk.gov.az/az/article/761/)

At the next stage, the following measures were taken in connection with the medical staff. On March 18, 2020, the President of the Republic of Azerbaijan signed a decree on strengthening the social protection of health workers participating in measures to combat a new coronavirus (COVID-19) infection [9].

In March, the President signed a decree, guided by Article 109, paragraph 32, of the Constitution of the Republic of Azerbaijan, in order to strengthen the social protection of health workers involved in the fight against and prevention of coronavirus (COVID-19) infection. According to the order, a periodic supplement to the salaries of employees of state medical institutions in the amount of 3-5 times the monthly official (tariff) salary shall be established [9].

In April, a law was signed to pay tuition fees to students belonging to vulnerable groups affected by the pandemic. According to the decision, these are:

- Recipients of targeted state social assistance

- both parents (or one is a single parent) or their legal representatives belong to any of the following categories:

- Persons with I and II degree disabilities

- Those registered as unemployed

- labor pensioners by age

- recipients of old-age social benefits [10].

From the first months of the pandemic, social isolation measures covering many areas of the country have also shown themselves in the field of education. Thus, in the first week of March, classes began to continue online. The fact that the education system is online has affected people studying medicine like other students.

Conducting classes online also had a negative impact on the quality of education. Due to the pandemic, nurses trained in their specialties had problems practicing in hospitals.

However, as a result of mass infections and the need for medical staff in the country, nurses and paramedics who are final-year students have begun to work in hospitals designed for people living with the virus.

The first ideas of student nurses and staff about the nature of the virus and how to provide effective care to patients were later developed when working with patients.

The constant work with patients and the atmosphere full of viruses led to the infection of student nurses and medical staff.

During a mass infection, people suspected of being infected may be tested at home without going to the hospital. Nurses who come home for tests are sometimes infected. Among those who died of the mass infection were nurses and doctors.

Student nurses care for infected patients, but sometimes these people become victims of the virus, and the deaths of patients they look after for days deal a devastating psychological blow to nurses. 
Because student sisters work with infected people most of the day, they experience some types of fatigue and weakness. They refuse to go home because they are infected with the virus, which causes them to see family members and stay away from home for months.

During the pandemic, student nurses, even if they have acquired a number of skills when working with patients, are at risk and their academic performance is changing due to distance learning.

\section{A Transdisciplinary Approach}

To understand and to assess these students' experiences in respect of their professional identity whilst working and studying through the Covid-19 pandemic, we are conducting a research project which reflect, transdisciplinary methodology and theoretic underpinning. The complexity of the issues involved in understanding identity and how the Covid-19 pandemic might have revealed the tension hidden without it will requires a phenomenological approach in the investigation which contextualises the identity study in the racial and political context of the presenting situation in higher education. The onto epistemological approach was used in this study to transcend the traditional disciplinary (or inter and multi-disciplinary) approach for we are seek an understanding of the student through their intersectional relationship with their transformation and emergence of their professional identity within the complex and confusing spaces that emerge from their ethnicity, within a professional environment in flux and which limits support mechanisms especially for BAME students. It is complex and an underdeveloped methodology for it accepts the notion of emergence as the creation of the way students formulate how they identify themselves and how they significant others. With an expanded approach which weaves the realities of person, institution and perceive world health issue linked to products and alienation the research is likely to produce symptomatic outcomes unlikely to improve the context in which the BAME students find themselves with COVID- 19 and beyond.

\subsection{Suggestions and Musings}

If these preliminary results are supported in the larger study it indicates that the university alone cannot be a causal force for change. The results indicate a blindness to ethnicity and even cultural racism from all those involved in the provision of care. It shows a lack of thought and duty of care. We would suggest a transdisciplinary response to the situation which might be revealed when the full results are presented. It is clear thought beyond the functionary use of human resources or protection, of investigations into potential systemic racism would be included in the problem as identified.

However, the process of systems solution has itself risks as all transdisciplinary study as it questions the hegemony of the powerful who control the notion of professional identity and behaviour associated with that. Moreover, this is like to reveal tension and anxieties within the students which need to be managed although not avoided in order to the impact of the COVID19 situation is seen as a global but also a distinctly personal issue.

Author Contributions: Research team members equally contributed.

Funding: This research received no external funding.

Conflicts of Interest: The authors declares no conflict of interest.

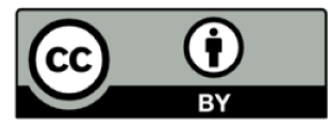

Copyright (C) 2021 by the authors. This is an open access article distributed under the Creative Commons Attribution License (https://creativecommons.org/licenses/by/4.0/), which permits unrestricted use, distribution, and reproduction in any medium, provided the original work is properly cited. 
Aygun Muradli and Paul Gibbs

Understanding the Impact of the COVID-19 Pandemic on Student Nurses - A Transdisciplinary Problem

\section{References}

[1] Perkin MR, Heap S, Crerar-Gilbert A, et al. (2020). Deaths in people from Black, Asian and minority ethnic communities from both COVID-19 and non-COVID causes in the first weeks of the pandemic in London: a hospital case note review. BMJ Open 2020;10:e040638. doi:10.1136

[2] Jackson, D., Bradbury-Jones, C., Baptiste, D.-L., Gelling, L., Morin, K., Neville, S., \& Smith, G. D. (2020). Life in the pandemic: Some reflections on nursing in the context of Covid-19. Journal of Clinical Nursing. https://doi.org/10.1111/jocn.15257.

[3] Swift, A.; Banks, L.; Baleswaran, A.; Cooke, N.; Little, C.; Mgrath, L.; Meechan-Rogers, Neve. A.; R.; Rees. H.; Tomlinson, A. and Williams, G. (2020) COVID-19 and student nurses: A view from England, Journal of Clinical Nursing, 29: 17/18. 3111-3114

[4] Eley, D., Eley, R., Bertello, M., \& Rogers-Clark, C. (2012). Why did I become a nurse? Personality traits and reasons for entering nursing. Journal of Advanced Nursing, 68(7), 1546-1555.

[5] Holmesland A-E. (2010). Open Dialogues in social networks: professional identity and transdisciplinary collaboration, International Journal of Integrated Care - ISSN 1568-4156, Volume 10.

[6] Lawrence, R. (2020). Advancing with Transdisciplinarity: Effective Responses for Coronavirus. Transdisciplinary Journal of Engineering \& Science, Vol. 11, pp. 189-200.

[7] Moorthy, A. and Sankar T.K. (2020). Emerging public health challenge in UK: perception and belief on increased COVID19 death among BAME healthcare workers, Journal of Public Health, Vol. 42, No. 3, pp. 486-492.

[8] Albott CS, Wozniak JR, McGlinch BP et al. Battle buddies: rapid deployment of a psychological resilience intervention for healthcare workers during the Covid-19 pandemic [published online ahead of print, 2020 Apr 24]. Anesth Analg 1213;2020:10.

[9] (https://president.az/articles/36210

[10] (https://nk.gov.az/az/article/761/)

\section{About the Authors}

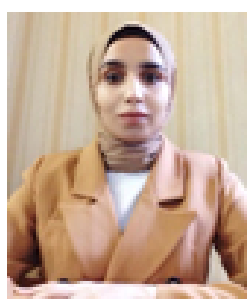

Aygun Muradli graduated from the Azerbaijan University of Languages in 2017 with a degree in French Studies from the Faculty of International Relations and Regional Studies. In 2019, he began to study at the Faculty of Social Work of the University of Azerbaijan, majoring in "Social work in various fields of life." The master's student chose the research topic "Social rehabilitation of children suffering from thalassemia" as a defense topic and began to write research and articles in this field. Currently, in addition to she final year education, she works as a trainer on social issues and disability.

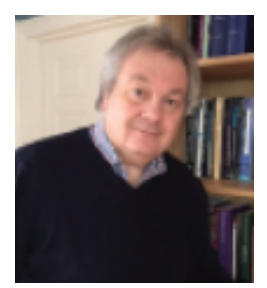

Dr. Paul Gibbs is Professor and Director of the Doctoral School, East European University. He is professor 
emeritus at Middlesex University, founder of the Centre for Education Research and Scholarship, and visiting professor at UTS Sydney and Azerbaijan university. His is a fellow of ATLAS as well as the Centre for Higher Education Policy, New College Oxford. He is an educator and researcher having taught notions of transdisciplinarity alongside social realism and Heideggerian hermeneutics. He has over 30 successful transdisciplinary professional doctorate students. He has published 20 books on topics ranging from the marketing of higher education to vocationalism and higher education and has published more than 100 academic articles. His particular approach to transdisciplinarity is informed by the works of Heidegger, Duns Scotus, and Deleuze and the theoretical insights of Basarab Nicolescu. He is also the series editor of SpringerBriefs on Key Thinkers in Education. 